\title{
A NOTE ON MOUNTAIN REEDBUCK REDUNCA FULVORUFULA FULVORUFULA AFZELIUS IN THE KRUGER NATIONAL PARK
}

\author{
L. R. IRBY
}

Caesar Kleberg Research Programme in Wildlife Ecology

Department of Wildlife and Fisheries Sciences

Texas $A$ \& $M$ University

College Station

Texas 77843

Abstract - This survey was conducted to obtain information on the mountain reedbuck population in the Kruger National Park for comparison with the population in the Loskop Dam Nature Reserve, Transvaal. During 93 hours of search effort, 36 mountain reedbuck sightings were recorded. All of the sightings were in the Malelane Hills on slopes above the Kwa Machiyaliwane drainage.

\section{Introduction}

Mountain reedbuck in the Kruger National Park (KNP) are found only in the Malelane Hills and along the Lebombo Mountain. The population is estimated to number 240 (Pienaar 1969). The status of this species in the Park is considered precarious by many people, but too little is known of its population structure and distribution to determine whether the population is declining or merely occupying a limited area of suitable habitat (Smuts, pers. comm.).

During February and September 1970, 19 days were spent in the Park surveying the mountain reedbuck population in the Malelane Hills. The object of the survey was to obtain information for comparison with the mountain reedbuck population in the Loskop Dam Nature Reserve located near Groblersdal, Transvaal. This paper is a condensation of observations made during the survey.

\section{Methods}

Mountain reedbuck were located in four ways:

1. Scanning hillsides with $7 \times 35$ binoculars and a $60 \times$ spotting scope;

2. Waiting by watering sites at dawn and sunset;

3. Walking ridgelines accompanied by a game scout;

4. Driving firebreak roads.

\section{Results}

Only six individual mountain reedbuck were sighted during 52,5 
hours of observation in February (Table 1). All sightings were in the hills along the Kwa Machiyaliwane drainage even though a comparable amount of time was spent in the vicinity of Khandizwe Hill and along the eMcwebeni drainage.

Table 1

Relative intensity of sampling and success using four techniques for sighting mountain reedbuck in the Kruger National Park

\begin{tabular}{l|c|c|c|c}
\hline & \multicolumn{2}{|c|}{ February } & \multicolumn{2}{c}{ September } \\
\cline { 2 - 5 } & $\begin{array}{c}\text { Observation } \\
\text { Time } \\
\text { Th) }\end{array}$ & $\begin{array}{c}\text { Animals } \\
\text { Sighted }\end{array}$ & $\begin{array}{c}\text { Observation } \\
\text { Time } \\
\text { (h) }\end{array}$ & $\begin{array}{c}\text { Animals } \\
\text { Sighted }\end{array}$ \\
\hline Spotting scope and & & & & \\
$\quad$ binoculars & 18,6 & 0 & 2,1 & 3 \\
Driving firebreaks & 15,0 & 4 & 3,9 & 0 \\
Waterhole counts & 3,0 & 0 & 4,3 & 0 \\
Foot transects & 15,9 & 3 & 30,0 & 27 \\
\hline
\end{tabular}

Efforts in September were more successful (Table 1). Of 30 animals sighted, at least 25 were not resightings. Group size ranged from one to six. Table 2 gives group size, composition, and general habitat information for the September sightings. All of the animals were located on hills above the Kwa Machiyaliwane drainage in Combretum woodland. Most of the groups were seen on west-facing slopes on a burned area east of the Kwa Machiyaliwane streambed. None were more than $5 \mathrm{~km}$ from the Matjulwana windpump.

\section{Discussion}

The low number of sightings recorded in February was probably due to visibility restrictions imposed by the fully-leafed vegetation. Several of the sightings in September would not have been made if the trees were not bare.

The presence of juveniles in September (Table 2) indicates that mountain reedbuck are reproducing in the Park and that lambs are surviving until the end of the dry season. Although the small sample size precludes any conclusions on the population trends of this antelope in the Park, the lamb to ewe ratio in the KNP is greater than the lamb to ewe ratio of the relatively stable Loskop population for the same period (Table 3 ). 
Table 2

Group size, composition, and site characteristics of mountain reedbuck sighted in the Kruger National Park during September 1970

\begin{tabular}{|c|c|c|c|c|c|c|c|c|}
\hline \multirow{2}{*}{ TIME } & \multirow{2}{*}{$\begin{array}{l}\text { GROUP } \\
\text { SIZE }\end{array}$} & \multicolumn{4}{|c|}{ GROUP COMPOSITION } & \multicolumn{3}{|c|}{$\begin{array}{c}\text { HABITAT } \\
\text { CHARACTERISTICS }\end{array}$} \\
\hline & & $\begin{array}{l}\text { Male } \\
(>1 \text { a) }\end{array}$ & $\begin{array}{l}\text { Female } \\
(>1 \text { a })\end{array}$ & $\begin{array}{l}\text { Imm. } \\
(<1 \text { a })\end{array}$ & $\begin{array}{l}\text { Un- } \\
\text { aged }\end{array}$ & $\begin{array}{l}\text { Slope } \\
\text { Face }\end{array}$ & $\begin{array}{l}\text { Ht. on } \\
\text { Slope }\end{array}$ & $\begin{array}{l}\text { Recent } \\
\text { Burn }\end{array}$ \\
\hline 1515 & 1 & - & 1 & - & - & W & $3 / 4$ & yes \\
\hline 0840 & 3 & - & 2 & 1 & - & SW & $3 / 4$ & yes \\
\hline 1012 & 2 & - & 2 & - & - & $\mathrm{S}$ & $3 / 4$ & yes \\
\hline 1655 & 6 & 1 & - & 1 & 4 & W & $1 / 4$ & yes \\
\hline 0705 & 1 & - & - & - & 1 & W & $3 / 4$ & yes \\
\hline 0810 & (whistle on & nly) & - & - & 1 & $?$ & $1 / 4$ & yes \\
\hline 0830 & 3 & - & 2 & - & 1 & SW & $2 / 3$ & yes \\
\hline 0855 & 5 & 1 & 2 & 2 & - & NW & $4 / 5$ & yes \\
\hline 0710 & 4 & 1 & 1 & 1 & 1 & $\mathrm{E}$ & $3 / 4$ & no \\
\hline
\end{tabular}

Table 3

Comparison of mountain reedbuck sightings in the Loskop Dam Nature Reserve during August-September 1970 with sightings in the Kruger National Park during September $1970^{\text {* }}$

\begin{tabular}{lcccccc}
\hline N & $\begin{array}{c}\text { Males } \\
(>1 \mathrm{a})\end{array}$ & $\begin{array}{c}\text { Females } \\
(>1 \mathrm{a})\end{array}$ & $\begin{array}{c}\text { Lambs } \\
(<1 \mathrm{a})\end{array}$ & Unaged & $\begin{array}{c}\text { Lamb : ewe } \\
\text { Ratio } \\
\text { (lambs per } \\
100 \\
\text { females) }\end{array}$ \\
\hline LOSKOP & 50 & 14 & 25 & 6 & 5 & 24 \\
KRUGER & 26 & 3 & 10 & 5 & 8 & 50 \\
\hline
\end{tabular}

" Groups sighted in intensive study areas at Loskop have been excluded.

The $24 \mathrm{~km}^{2}$ section of the Kwa Machiyaliwane drainage surveyed yielded a minimum count of 25 mountain reedbuck. Exclusion of $3 \mathrm{~km}^{2}$ of flats associated with the main streamcourse gave a minimum density of 1,2 mountain reedbuck per $\mathrm{km}^{2}$ of slope habitat. A similar treatment of sightings at Loskop during June-August 1973 (Irby 1973), gave a minimum count of 205 individuals on $49 \mathrm{~km}^{2}$ for a minimum density of 4,2 per $\mathrm{km}^{2}$ of slope habitat. While the two counts are not directly 
comparable, since the search intensity was greater at Loskop, the data indicate that the Kwa Machiyaliwane sub-population is less dense than that of Loskop.

The absence of sightings around Khandizwe Hill and along the eMcwebeni drainage may indicate a decline in the population, and a subsequent decrease in the range occupied, or only insufficient effort expended to locate individuals in a very sparse population. New growth on burned grass clumps in the Kwa Machiyaliwane area could have concentrated mountain reedbuck in that region. A mass migration from the eMcwebeni drainage to this burn seems unlikely since comparable burns, with no mountain reedbuck, were observed in the eMcwebeni drainage, and mountain reedbuck are territorial.

\section{Acknowledgements}

I wish to thank Dr. U. de V. Pienaar and the National Parks Board of Trustees for allowing me to work in the Kruger National Park and the staff of the Park for the guidance and assistance provided during my stay. Dr. S. L. Beasom deserves thanks for reviewing this manuscript. Funding for this study was provided by the Mammal Research Institute, University of Pretoria; the Caesar Kleberg Research Program in Wildlife Ecology, Texas A \& M University; and the National Science Foundation, Washington, D.C. Material presented in this paper will be used for partial fulfillment of the requirements for a Ph.D. degree from Texas A \& M University. This manuscript is Texas Agricultural Experiment Station Technical Article No. TA 12059.

\section{REFERENCES}

IRBY, L. R. 1973. Mountain reedbuck in the Transvaal. Unpublished annual report of the Caesar Kleberg Research Program in Wildlife Ecology. 108-115.

PIENAAR, U. de V. 1969. Predator-prey relationships amongst the larger mammals of the Kruger National Park. Koedoe 12:108-176. 